\title{
DAMPAK PERUBAHAN SOSIAL DAN BUDAYA TERHADAP PENDIDIKAN
}

\author{
Herlina \\ Email: 2010128320002@mhs.ulm.ac.id \\ Program Studi Pendidikan IPS Fakultas Keguruan dan Ilmu Pendidikan \\ Universitas Lambung Mangkurat \\ Banjarmasin
}

\begin{abstract}
Abstrak
Peruabahan Sosial adalah perubahan yang terjadi karena adanya unsur-unsur yang menyebabkan ketidakpuasan dalam kehidupan sehingga mengalami perubahan. Sedangkan Perubahan Kebudayaan adalah perubahan yang terjadi akibat dari adanya ketidaksesuaian antara unsur-unsur kebudayaan yang saling berbeda sehingga terjadi ketidaksesuaian dalam kehidupan masyarakat. Unsur-unsur yang dimaksud ialah bahasa, sistem pengetahuan, organisasi sosial, sistem religi, kesenian, sistem mata pencaharian dan sistem teknologi. Hubungan antara perubahan sosial dengan pendidikan adalah terjadinya perubahan pada struktur sosial dan tatanan dalam kehidupan masyarakat yang termasuk didalamnya adalah pendidikan. Dampak yang ditimbulkan dari adanya perubahan sosial tersebut pada pendidikan yaitu dapat menimbulkan dampak yang positif dan ada juga yang negatif.
\end{abstract}

\section{PENDAHULUAN}

Manusia adalah makhluk sosial yang pasti mengalami suatu perubahanperubahan, baik dari segi sosial, norma sosial, ataupun pola perilaku serta lembagalembaga lainnya. Ada perubahan yang memiliki pengaruh besar terhadap kehidupan manusia, ruang lingkup perubahan tersebut dapat meliputi unsur-unsur kebudayaan yaitu bahasa, sistem pengetahuan, organisasi sosial, sistem religi, kesenian, sistem mata pencaharian dan sistem teknologi. Kehidupan merupakan hal yang dinamis, oleh sebab itu mengalami perubahan, oleh karena itu manusia juga mengalami perubahan baik ia sebagai individu maupun kelompok masyarakat. Dalam perubahan yang terjadi pada setiap individu atau kelompok masyarakat bisa mengalami perubahan seperti berubahnya perilaku individu, berubahnya tatanan kehidupan masyarakat, oleh karena itu perubahan juga dapat terjadi pada pendidikan. Karena kehidupan manusia bersifat 
dinamis, maka perubahan yang akan terjadi adalah suatu hal yang pengaruhnya akan berdampak pada kehidupan. Penemuan-penemuan baru yang merupakan penyebab dari perubahan tanpa disadari yaitu dapat berdampak pada pendidikan. Suatu perubahan yang terjadi sekecil apapun akan berdampak pada tatanan kehidupan masyarakat lainnya, contohnya pada perubahan gaya berpakaian yang akan menghasilkan perekenomian masyarakat lain akibat dari gaya berpakaian yang baru atau model terbaru yang akhirnya akan dibeli masyarakat untuk mengikuti trend tersebut. Sama halnya dengan pendidikan, peruabahan sosial akan berdampak pada pendidikan tersebut.

\section{METODE PENELITIAN}

Metode penelitian yang digunakan ialah metode penelitian kualitatif. Metode kualitatif adalah metode untuk menyelidiki objek yang tidak dapat di ukur dengan angka-angka. Pendekatan ini cenderung dengan menggunakan analisis dari berbagai dokumen-dokumen atau jurnal-jurnal ilmiah yang di dapat sehingga menghasilkan data deskriptif yang rinci dari suatu fenomena yang diteliti.

\section{PEMBAHASAN}

Perubahan Sosial adalah berubahnya struktur sosial atau tatanan sosial dalam kehidupan masyarakat. Perubahan tersebut merupakan suatu hal yang terjadi akibat dari ketidakpuasan seseorang dalam suatu hal yang menyebabkan ingin berubah. Sedangkan perubahan kebudayaan adalah perubahan yang terjadi akibat dari adanya ketidaksesuaian antara unsur-unsur kebudayaan yang saling berbeda sehingga terjadi ketidaksesuaian dalam kehidupan masyarakat. Unsur-unsur yang dimaksud ialah bahasa, sistem pengetahuan, organisasi sosial, sistem religi, kesenian, sistem mata pencaharian dan sistem teknologi. Perubahan Sosial dan budaya adalah suatu gejala umum dari berubahnya struktur sosial dan pola yang ada dalam kehidupan masyarakat yang terjadi sesuai dengan sifat dasar manusia yang selalu ingin mengalami perubahan dikarenakan berbagai banyak faktor. Faktor tersebut ialah faktor eksternal dan internal, faktor eksternal seperti pengaruh kebudayaan masyarakat lain, pengaruh lingkungan 
fisik, terjadinya pemberontakan dan peperangan. Sedangkan faktor internal yaitu perubahan jumlah penduduk, penemuan-penemuan baru, dan adanya pertentangan dalam masyarakat. Oleh karena itu dapat disimpulkan bahwa perubahan sosial budaya merupakan perubahan yang terjadi pada struktur sosial yang termasuk didalamnya aspek kebudayaan serta nilai-nilai maupun pola tingkah laku dalam suatu masyarakat.

Pendidikan suatu bentuk usaha dari perwujudan seni dan budaya manusia yang terus berubah dan berkembang sebagai suatu alternatif yang paling rasional yang memungkinkan untuk melakukan perubahan. Perubahan Sosial yang mana telah dijelaskan diatas bahwa perubahan sosial adalah perubahan yang terjadi pada struktur sosial dan tatanan dalam kehidupan masyarakat termasuk didalamnya adalah pendidikan, karena pendidikan pada dasarnya ada dalam masyarakat, baik itu pendidikan formal, informal maupun non-formal. Pendidikan ada karena adanya suatu masyarakat yang berperan didalamnya, maka pendidikan dan masyarakat memilki hubungan yang erat dan saling berkaitan. Oleh karena itu pendidikan merupakan suatu pengabdian masyarakat sehingga masyarakat mengalami perubahan dan terus berkembang seiring berkembangnya zaman dengan adanya suatu pendidikan. Peruabahan sosial yang terjadi secara cepat maupun lambat akan berdampak pada pendidikan. Contohnya dengan bertambahnya jumlah penduduk maka cepat atau lambat diperlukannya sekolah untuk menampung siswa tersebut, sehingga sarana pendidikan akan memerlukan bangunan yang banyak untuk membangun sekolah tersebut, selanjutnya seiring dengan perkembangan zaman dan perubahan sosial terus terjadi maka kebutuhan masyarakat terhadap pendidikan guna menghadapi kehidupan yang kompleks akan sangat memerlukan pendidikan dalam mempersiapkan masyarakat itu sendiri dalam menghadapi perkembangan zaman tersebut.

Dampak Perubahan Sosial dari berkembangnya teknologi yaitu dapat dengan mudah mengakses internet bagi masyarakat atau peserta didik untuk melakukan suatu pekerjaan atau hal-hal yang besifat positif, namun ada juga masyarakat yang memanfaatkan teknologi untuk membuka internet dengan yang tidak bermanfaat atau yang bertentangan dengan norma agama. Adapun dampak lain yang ditimbulkan dengan 
adanaya perubahan sosial terhadap pendidikan yaitu dengan berkembangnya kurikulum mampu menjwab tantangan dalam perubahan, dan perubahan pada sistem manajemen pendidikan yang berorientasi pada kualitas pembelajaran yang unggul sehingga menghasilkan output yang berkualitas. Perubahan sosial yang terjadi pada masyarakat atau suatu individu sangat berpengaruh terhadap pendidikan, namun tidak semua perubahan sosial dapat berdampak positif, tetapi perubahan sosial juga akan menimbulkan dampak yang negatif. Dampak perubahan sosial pada pendidikan dari segi positif adalah proses belajar mengajar akan menjadi mudah karena bantuan dari teknologi, siswa dapat mengembangkan wawasan dan kreatifitas seluas-luasnya, serta fasilitas pembelejaran menjadi lebih modern, oleh karena itu dapat meningkatkan taraf pendidikan dalam kehidupan masyarakat sehingga dapat menghasilkan manusia yang siap dalam mengahdapi perkembangan zaman atau peruabahan sosial yang terjadi. Sedangakan dampak negatif yang ditimbulkan dari suatu teknologi yaitu banyaknya pengaruh budaya dari luar yang merusak pada perilaku individu dan struktur kehidupan masyarakat. Siaran televisi ataupun internet yang tidak baik menjadi suatu tantngan bagi pendidikan, karena kalau tidak diantisipasi maka akan berdampak buruk bagi individu atau masyarakat itu sendiri.

\section{SIMPULAN}

Perubahan Sosial dan budaya adalah suatu gejala umum dari berubahnya struktur sosial dan pola yang ada dalam kehidupan masyarakat yang terjadi sesuai dengan sifat dasar manusia yang selalu ingin mengalami perubahan dikarenakan berbagai banyak faktor, baik itu faktor internal maupun eksternal. Perubahan Sosial yang terjadi pada masyarakat tentunya juga berpengaruh pada pendidikan, karena pendidikan pada dasarnya ada dalam masyarakat, baik itu pendidikan formal, informal maupun non-formal. Peruabahan sosial yang terjadi secara cepat maupun lambat akan berdampak pada pendidikan. Contohnya dengan bertambahnya jumlah penduduk maka cepat atau lambat diperlukannya sekolah untuk menampung siswa tersebut, sehingga sarana pendidikan akan memerlukan bangunan yang banyak untuk membangun sekolah tersebut. Dampak yang ditimbulkan akibat dari perubahan sosial dan budaya yaitu 
menimbulkan dampak yang positif dan ada juga yang negatif. Dampak positifnya yaitu dapat meningkatkan taraf pendidikan dalam kehidupan masyarakat sehingga dapat menghasilkan manusia yang siap dalam mengahdapi perkembangan zaman atau peruabahan sosial yang terjadi. Sedangkan dampak negatifnya yaitu menjadikan pendidikan akan ketidaksiapan dalam perubahan yang cepat, menjadikan siswa bersifat individualisme, banyaknya pengaruh budaya dari luar yang merusak pada perilaku individu dan struktur kehidupan masyarakat. 


\section{DAFTAR PUSTAKA}

Abbas, E. W. (1996). Bab-Bab Antropologi. Penyunting tulisan Fudiat Suryadikara. Banjarmasin: EWA Book Company.

Abbas, E. W. (2002). Banjarbaru. Lembaga Pengkajian Kebudayaan dan Pembangunan Kalimantan.

Abbas, E. W. (2013). Masyarakat Dan Kebudayaan Banjar Sebagai Sumber Pembelajaran Ilmu Pengetahuan Sosial (Transformasi Nilai-Nilai Budaya Banjar Melalui Ajaran dan Metode Guru Sekumpul [Thesis (Bachelor)]. Universitas Pendidikan Indonesia.

Abbas, E. W. (2013). Mewacanakan Pendidikan IPS (Cetakan Kedua). WAHANA Jaya Abadi.

Indriyani, I. E., Syaharuddin, S., \& Jumriani, J. (2021). Social Interaction Contents on Social Studies Learning to Improve Social Skills. The Innovation of Social Studies Journal, 2(2), 93-102.

Lubis, M. S. A. (2018). DAMPAK PERUBAHAN SOSIAL TERHADAP PENDIDIKAN. Al-Ikhtibar: Jurnal Ilmu Pendidikan, 5(2), 513-523.

Mutiani, M., Supriatna, N., Abbas, E. W., Rini, T. P. W., \& Subiyakto, B. (2021). Technological, Pedagogical, Content Knowledge (TPACK): A Discursions in Learning Innovation on Social Studies. The Innovation of Social Studies Journal, 2(2), 135-142.

Norhayati, N., Abbas, E. W., \& Putra, M. A. H. (2020). Social Interaction Pattern Jelai Riverbanks South Basirih. The Innovation of Social Studies Journal, 1 (1), 1220.

Putro, H. P. N., Jumriani, J., Darmawan, D., \& Nuryatin, S. (2020). Social Life of the Community: Perspective of Riverbanks Community in Sungai Jingah, Banjarmasin. The Kalimantan Social Studies Journal, 1(2), 151-158.

Wahib, A. (2019). DAMPAK PERUBAHAN SOSIAL BUDAYA PADA PENDIDIKAN: Dampak Perubahan Sosial. Jurnal Paradigma, 7(1).

Zainuddin, M. Dampak Perubahan Sosial Budaya terhadap Perkembangan Pendidikan di Indonesia. 